\title{
Revisiting production and ecosystem services on the farm scale for evaluating land use alternatives
}

\author{
Frederik Lerouge $^{1^{*}}$, Kurt Sannen $^{2}$, Hubert Gulinck ${ }^{3}$, Liesbet Vranken ${ }^{1}$ \\ ${ }^{1}$ KU Leuven, Department of Earth and Environmental Sciences, Division Bio-Economics, Celestijnenlaan 200E, 3001 \\ Heverlee, Belgium \\ ${ }^{2,}$ Het Bolhuis', Asdonkstraat 49, 3294 Molenstede-Diest \\ ${ }^{3} \mathrm{KU}$ Leuven, Department of Earth and Environmental Sciences, Division Forest, Nature and Landscape, Celestijnenlaan 200E, \\ 3001 Heverlee, Belgium \\ *Corresponding author: Tel.:+32-16-32.97.72, Fax: +32-16-32.97.60, e-mail address: Frederik.lerouge@ees.kuleuven.be
}

This document is a postprint version. The published version can be found here (doi:10.1016/j.envsci.2015.11.015).

\begin{abstract}
Urbanization pressure increases the demand on remaining open spaces to deliver food and biomass, as well as other ecosystem services, but it is often paired with a reduced capacity to deliver these services. This calls for an integrated and innovative use of the remaining space.

However, current spatial planning paradigms are not always adapted to face these new challenges. In many regions, an important aspect of spatial planning in relation to agriculture is still the pragmatic and monofunctional allocation of land use between vocal stakeholders. This is rarely paired with a regional view on the effective or desired quantity of services provided by this open space. Since land use policies increasingly need to strive for resilience on top of diversification of services, assessments of the servicing capacity and sustainability of land uses are needed.

This paper presents a framework to assess all ecosystem services (i.e. marketable and non-marketable ES) delivered by conventional as well as innovative land uses. The framework is then used to assess land use strategies at the scale of an unconventional case farm in Flanders, Belgium. The analysis combines spatial and economic analysis of land use alternatives and illustrates some shortcomings of usual ecosystem valuation tools. Our findings illustrate that land use evaluation might be biased against unconventional land management alternatives. The proposed framework provides land planners with a way to assess and arbitrate between land sharing and land sparring options more accurately. The approach can help to optimize land use from the societal perspective, and allows for benchmarking farm-level land use alternatives by comparing the services they deliver.
\end{abstract}

Keywords: bioproductive land; land management; ecosystem services; land sharing vs sparing; multifunctional land use 


\section{Introduction}

Population pressure results in an increasing demand for food and bio-energy products and hence also in an increasing demand for agricultural land (Meyfroidt et al., 2013; Tscharntke et al., 2012). This demand is in competition with the demand for land for residential, conservation, forestry, recreational, and other purposes (Radford and James, 2013; Zasada, 2011). Traditionally, spatial planning has focused on the allocation of land to space demanding sectors and on minimizing spatial conflicts. This further exacerbates the existing sectoral polarization. This approach falls short in considering present-day demands for multifunctionality, sustainability, ecosystem services, resilience and adaptive governance. Although an integrative and place-based approach to land management is highly needed, it is largely missing (Bomans et al., 2010; Termorshuizen and Opdam, 2009). Particularly in fragmented and hybrid peri-urban landscapes, the relation between the availability of space and the potential societal services it is able to provide needs further exploring. Here, interfaces between different land uses and associated actors are plenty, and there is great potential for innovative concepts for land use allocation.

Concepts of multifunctionality and Ecosystem Services (ES) already bridge the distinction between traditional sectors like agriculture, nature and forestry. The ES concept (Haines-Young and Potschin, 2010; Millennium Ecosystem Assessment, 2005) has proven to be useful in supporting resource management decisions (Hauck et al., 2013; Wainger et al., 2010). In the framework of the Biodiversity Strategy 2020, the EU called its member states to assess and map the condition of ES within their territory. This development will provide new opportunities to incorporate the ES concept into decision making. Nonetheless, the application to real-life land management decisions remains challenging (Crossman et al., 2013; Portman, 2013). There is a continuing need to evaluate the available tools against existing cases (Dale and Polasky, 2007; Estrada-Carmona et al., 2014).

Decision makers relying on such tools face a number of challenges. Since ES assessment tool estimates are often based on indicators derived from conventional land uses, there is a real risk they fail to recognize the potential of less conventional forms of land use, like for example organic farming. Foley et al. (2005) present a conceptual framework which shows that agro-ecological cropland management might support a larger portfolio of ES than production-oriented cropland. Examples are cultural services such as recreation and landscape amenity, as well as regulating services such as flow regulation and pest control (HainesYoung and Potschin, 2010; Zasada, 2011). These ES need to be recognized (Daniel, 2008; Swinton et al., 2007). In the light of food and biomass production, the principal challenge is to simultaneously assess and maximize production as well as the other ES provided by open space (Balmford et al., 2012) which inevitably implies trade-offs. Moving away from a predominantly production-oriented to a post-productivist view on the landscape will aid land managers and planners in recognizing opportunities and innovations within and across landscapes.

Although the awareness increases that agricultural systems provide other services besides food and biomass production, many of these services are non-marketable. Because free markets fail to provide sufficient incentives for delivering these services, a dominant production logic may push agricultural systems towards a state that is sub-optimal from a 
societal point of view (Ghaley et al., 2013). Hence, there is a need to evaluate land use scenarios with respect to the delivery of provisioning, as well as the non-provisioning services (de Groot, 2006; Swinton et al., 2007). Positive externalities, i.e. in this case non-marketable, are at risk of being ignored or underestimated. This is particularly the case for complex, fragmented and urbanized landscapes (Cook et al., 2012; Laterra et al., 2012).

Earlier work on evaluating land use and management in relation to food production from the ES perspective is largely focussing on trade-offs and synergies at the landscape scale, a.o. by exploring bundles of ES (Castro et al., 2014; Turner et al., 2014). Jackson et al., (2013) present a toolkit ('Polyscape') that allows to calculate a limited number of ES and evaluate trade-offs between them. They explicitly opted for a qualitative analysis of the output instead of a complex quantitative economic assessment. The latter contains several layers of complexity and might therefore suffer from a reduced transparency. Burkhard et al. (2012) apply a spatially explicit approach to map the ex post implications of land use changes over time, using non-monetary valuation of ES. Using indicator-based non-monetary valuation of ES along a rural-urban gradient, Radford \& James (2013) were able to point out the negative impact of urbanization on ES delivery, as well as the need for more green space in (peri)urban settings.

While the above approaches are useful to point out trade-offs between ES in relation to the spatial context, they fail to address the potential to deliver more ES by managing available or new green spaces in an alternative way. Our approach differs in a couple of ways. It is an ex ante assessment of potential land use changes using monetary valuation of ES. The paper develops an evaluation framework that integrates non-marketable services as well as nonconventional production methods in its ES valuation. By doing this and comparing the outputs of the model to actual data, the paper aims to assess limitations of usual tools used for ES valuation. These do not take into account non-conventional production methods/nonmarketable ES and, by doing so, might estimate their contribution wrongly. Our analysis also differs in terms of scale. Selecting the appropriate scale is crucial in ES evaluations (Burkhard et al., 2012). The landscape scale is often considered most appropriate for an integrated analysis of spatial transformations (Pinto-Correia and Kristensen, 2013). However, by systematically focusing on larger scales, innovative land use at a smaller scale risks to remain under the radar of research. Estrada-Carmona et al. (2014) indicated a clear need for in-depth analysis of individual cases of integrated land management to complement to landscape scale research efforts. Therefore, we look into the societal benefits delivered through different land use strategies on the scale of an innovative case farm. The farms combines livestock production with nature development. Through its multifunctional land use the case farm bridges the gap between the often competing sectors of agriculture and nature. Many of the societal benefits of this form of innovative land use are easily overlooked in planning practices. This paper that aims to provide land planners with a way to assess land sharing and land sparring options more accurately. Collaboration with the farmer as the main stakeholder has been an important element. The level of detail at this scale of analysis allows us to point out key characteristics of the production model, explaining its innovative aspects. A clear view on these innovations can be essential for sound policy decision making.

The case farm is located in Flanders, the northern part of Belgium. Flanders is a largely peri-urban region with high population pressure. The Flemish landscape is highly fragmented 
and urbanized, with a high degree of private land ownership and considerable pressure on the remaining open space (Bomans et al., 2010; Meeus and De Decker, 2013; Verhoeve et al., 2015). Therefore, the case of Flanders is considered illustrative for many other peri-urban regions that experience high urbanization pressures. Some challenges and lock-ins for spatial planning can be identified when developing integrative approaches to land allocation in this region. First, the use of space in Flanders is intrinsically multifunctional, while spatial planning policies are largely monotypic in nature (Kerselaers et al., 2013). For agriculture, there is a clear policy focus on productive functions (Leinfelder, 2007). As a consequence, current spatial planning frameworks have difficulties facilitating multifunctional land use strategies. Second, a high spatial fragmentation causes the role and potential of many small fragments to be systematically underrated. Third, the limited view on privatization (e.g. intake of agricultural land by residential gardens) and domestication (e.g. use of agricultural land for hobby activities) trends (Dewaelheyns et al., 2014; Gulinck et al., 2013) allows some transformations to remain under the radar of policy. Finally, there is a discrepancy between a relatively static policy framework and a dynamic reality shaped by a.o. climate change, biodiversity loss, market volatility and shifting norms.

\section{Conceptual approach}

To develop an integrative regional approach for the evaluation of land use strategies for open spaces, the concept of 'bioproductive land' is introduced. Bioproductive land is defined as the area providing services through primary production processes. It includes semi-natural as well as agricultural ecosystems. Like multifunctional agriculture (Boody et al., 2013; Zasada, 2011), bioproductive land is key in providing a multitude of provisioning, cultural, regulating and maintenance services. By also incorporating non-provisioning ES, we acknowledge both the importance of production, while other essential sustainability concepts are not neglected. Also, several non-agricultural forms of land use exist within agricultural space, and non-agricultural open space is considered bioproductive land as well. The concept thus comprehends more land than what would traditionally be considered when assessing the potential of multifunctional agriculture. While farmers inevitable play a significant role in nurturing multiple functions and services in the landscape, a strict sectoral vision on rural land use can impede innovative research. We agree with Pinto-Correia \& Kristensen (2013) that trading sectoral for place- and landscape based approaches can facilitate new pathways for innovative land use. Bioproductive land also expands on the concept 'green infrastructure' as proposed by Ahern et al. (2014), since it is not limited to protected networks and systems, nor to urbanized spaces. The concept of bioproductive land also allows to take several forms of unconventional land use into account. These include land use changes that are not or insufficiently picked up by monitoring and feedback systems, like the use of pastures for hobby horses, or non-agricultural use of farm buildings (Bomans et al., 2010, 2009; Verhoeve et al., 2015). Our case is an example of farm diversification and recreational use of seminatural land, which is an underrated transformation in Flanders. Much of the area used for production is not situated within the statutory demarcated agricultural space.

While agricultural output is traded on the market, most other ES outputs in the assessment are not traded, although they deliver valuable services for the society. By taking 
them into account we are assessing the optimality of land use scenarios from a societal point of view rather than from a private or farmer's point of view. Depending on the availability of data and aggregation techniques, this allows to take potential externalities into account in evaluating land use alternatives. By combining ecological and economic analysis, including non-marketable benefits, and involving the farmer as the main stakeholder in the research, the analysis conforms to earlier recommendations for assessments to support adaptive land management and planning (de Groot, 2006).

\section{Case Farm Description}

The case farm is an organic farm that was established in 2001 on the land of a former conventional dairy farm. In 2013, it covers about 112 hectares, which is not insignificant in the small scale peri-urban Flemish landscape (the mean area of a Flemish farm in 2011 being 23.6 ha, Vuylsteke et al. (2014)). Most of this area is located within nature reserves. This case was selected because it represents a for Flanders relatively rare and innovative form of integrating agro-ecological production with nature development. The farm is located at $51^{\circ} 00^{\prime} 47^{\prime \prime} \mathrm{N} ; 5^{\circ} 02^{\prime} 41^{\prime} \mathrm{E}$, in two subcatchments of the Demer river (Figure 1).

Atmospheric nitrogen deposition continuously add nutrients to natural grasslands (Stevens et al., 2011). Since grassland floristic biodiversity generally decreases with an increasing nutrient content, semi-natural grassland management in Flanders has to deplete nutrient stocks (Oelmann et al., 2009; Stevens et al., 2011). Consequently, this management typically produces biomass waste streams from mowing. In general, this biomass is less suited for conventional livestock breeds, both in terms of digestion and nutritional intake. Therefore, ecological farms typically resort to more sturdy and self-reliant livestock breeds (Bedoin and Kristensen, 2013). The case farm uses two rustic breeds, 'Kempisch Roodbont' cattle and 'Ardense Voskop' sheep. Both are able to digest low-quality feeds and convert it to highquality animal protein (i.e. dairy products and meat). Both breeds are threatened by extinction so that preserving their genetic resources can be considered as an additional provisioning service delivered by the farm system.

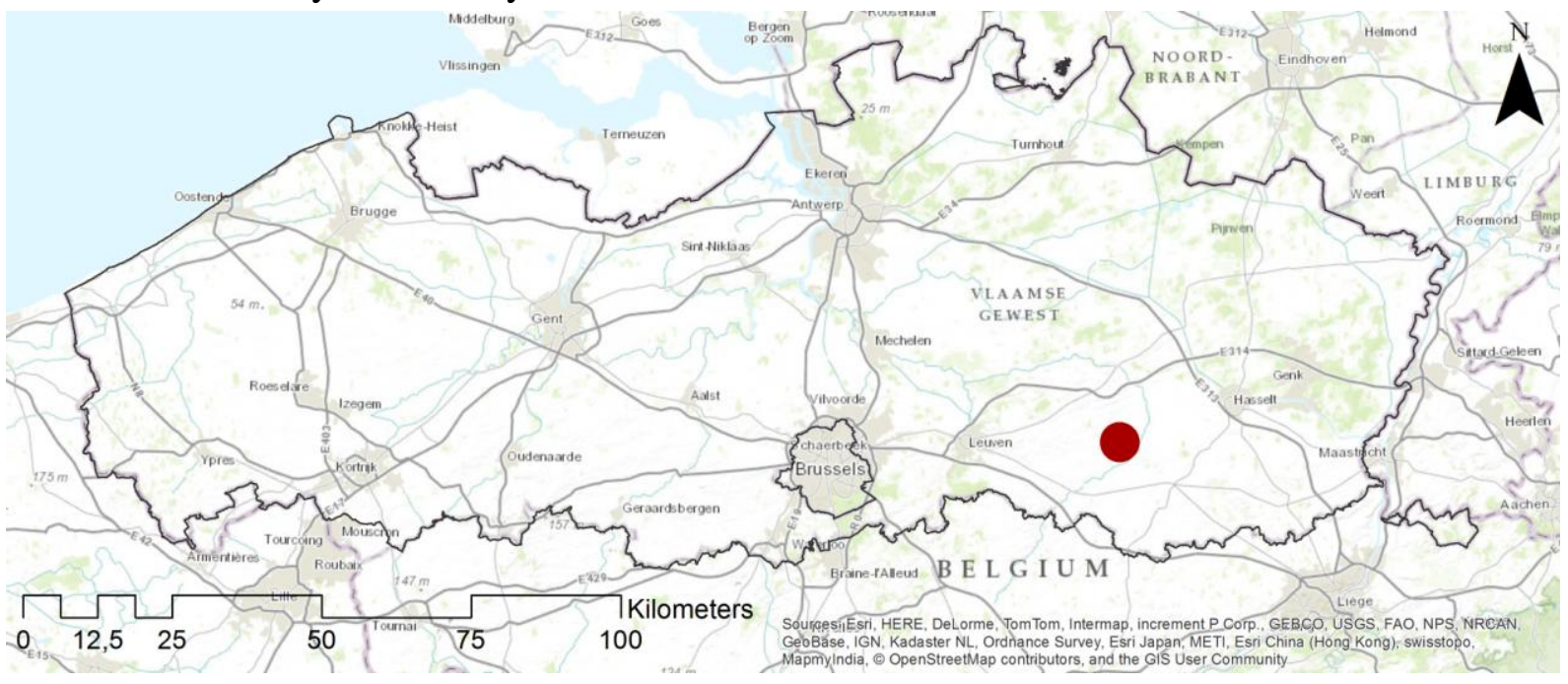

Figure 1. Location of the case farm in Flanders 


\section{Methodology}

\subsection{Data compilation}

The farm parcels were mapped in ArcGIS 10.1. Land use was based on the farms register and the Biological Valuation Map (AGIV, 2010), updated using aerial imagery (Aerodata International Surveys, 2007) combined with verification in the terrain (early 2013). The Biological Valuation Map is a spatially explicit dataset containing a categorical ecological valuation of the land cover, as well as detailed information on the vegetation types on a subparcel level. The following data were added on the parcel level: production data (grazing and cutting) compiled from the farm register, soil texture and moisture data (AGIV, 2006), the Habitat map v5.2 containing habitats falling under the EU Habitat Directive (INBO, 2010), flood risk zones (VMM, 2006), and the presence of woody vegetation such as hedgerows, isolated trees and orchards (ANB, 2013, 2010). Livestock and feed production figures were attributed to the respective parcels by a parcel-by-parcel breakdown of the livestock movement and mowing registers.

\subsection{Evaluation of ES delivered by bioproductive land}

We use a biophysical indicator-based approach to benchmark potential land use alternatives by comparing the services they would deliver. This sets the foundation for optimizing spatial productivity under various land use and land management rationales. The existing extensive farm model is used as the baseline scenario, referred to as the Reference scenario. On the same land, we assume three counterfactual normative land use scenarios, which we call IntensiveMIN, IntensiveMAX and IntensiveSRC. These alternatives are described in detail in Section 4.3.In a pairwise comparison of the Reference with each of these alternatives, the differential delivery of ES is calculated, and subsequently aggregated using monetary valuation. The benefit of using monetary valuation here is that it allows to assess the private as well as the social value attached to ES.

Differences in ES delivery among different land use alternatives were estimated using the "Ecosystem Service Valuation Tool" developed by VITO (Broekx et al., 2013). The land use alternatives include a reference scenario based on the actual land use, and some more conventional land use scenarios described in detail below.

To better take local biophysical variations in the landscape into account, geographically separated clusters of parcels were evaluated independently. The evaluation of cultural services was done for the case farm as a whole, because the used value function tends to overestimate the value of cultural ES when applied to very small areas. The valuation tool provides a lower and upper estimate for the value of the considered ES, based on the 25 and 75 percentile values of the calculated values, and the comparison is based on the minimal estimates to avoid potential overestimation of the positive externalities. Subsidies are not taken into account in the evaluation.

The provisioning services -crops and livestock values as well as wood production valueunder the Reference scenario were quantitatively estimated based on accountancy data of the farm case and interviews with the case farm manager. The tool's calculation of provisioning services is based on a representative sample of Flemish farms, including mainly intensive, 
non-organic farms. Therefore the tool is considered to be robust for the calculation of provisioning services under intensive land use scenarios. These are estimations of net production value, being the market value of the production output minus costs and excluding subsidies, and are based on average income registrations over various sectors ( $n=749)$ (Van Broekhoven et al., 2012). For the quantification, this net production value figures are combined with crop registration and soil suitability data, which were determined in a GIS environment. Calculation of feed production values is not based on market prices since most feed is cultivated for on-farm use. Instead, gross livestock revenues are distributed over the area used for feed production (Liekens et al., 2013b). Quantitative assessment and valuation of wood production is done by multiplying the area under tree cover with matched productivity figures (Jansen et al., 1996), related to the type of forest and the typology of the physical system. The effective wood production is calculated by multiplying the results with a harvest factor. This factor represents the estimated percentage wood actually harvested in relation to the maximal potential harvest. Valuation is done by multiplying this estimate by the average market prices $(2009$ - 2012) for standing timber. Specific management costs are considered negligible in this approach.

For the regulating services, fine particle filtration ('air quality'), carbon sequestration in soil and biomass, and nitrogen $(\mathrm{N})$ and phosphorus $(\mathrm{P})$ sequestration in soil were evaluated. The air quality estimations in captured particulate matter $<10 \mu \mathrm{g}$ (PM10, in kg/year) are based on indicators by Oosterbaan et al. (2006), estimating the fine particle filtration capacity per land cover type. Broekx et al. (2013) point out that these indicators are consistent with several other, more recent studies. PM10 is the dominant factor in airborne pollutant related health issues in Flanders. Valuation is done by multiplying these estimates by a generic avoided medical cost of $54 € / \mathrm{kg} \mathrm{PM}_{10}$, derived from De Nocker et al. (2010). Carbon sequestration in biomass was estimated based on yearly growth figures multiplied with biomass expansion factors to include root and branch growth. The amount of carbon is derived using species-specific carbon density figures (van de Walle et al., 2005). This approach takes tree species and soil conditions into account. For soil carbon storage the regression model by Meersmans et al. (2008) is applied, estimating maximal potential carbon stocks taking soil texture class, water table changes and land use into account. The potential amount of $\mathrm{N}$ and $\mathrm{P}$ are based on the potential carbon content. Valuation is based on marginal reduction costs for $\mathrm{N}$ and $\mathrm{P}$ (Broekx et al., 2009), and estimated avoided cost of carbon reduction, according to De Nocker et al. (2010).

The calculation of cultural services was based on a stated preference method (de Groot, 2006; Hoyos, 2010). A similar approach was used by Costanza et al. (1997) to estimate the value of world ES. We used a value function, calculated for Flanders and representing the willingness to pay (WTP) for the conversion of agriculture to nature or vice versa (Broekx et al., 2013; Liekens et al., 2013a). This value function combines values for recreation, amenity and biodiversity, and is derived from a choice experiment (Liekens et al., 2013a). Choice experiments are commonly applied to determine preferences and associated WTP as a measure for valuation of changes to landscape management and land use (Bateman et al., 2009; Broch et al., 2013; Christensen et al., 2011; De Valck et al., 2014; Ryffel et al., 2014). The function we apply has been demonstrated to be robust over time (Schaafsma et al., 2014). First, the number of households within a $50 \mathrm{~km}$ radius, i.e. where the value function is larger 
than zero, is determined. This number is multiplied with a mean WTP based on the type of ecosystem, species richness, accessibility, surrounding land use, size and distance to the household using a distance decay function.

\subsection{Land use alternatives for crop and livestock production}

The Reference scenario describes the case study area as it is currently cultivated, in a combination of ecological meat production and livestock breeding with nature management and ecotourism. Cultivated grasslands and semi-natural grasslands are combined, but the share of semi-natural grasslands is high and the livestock production is extensive. This results in a high potential for nature conservation, but also in a penalty in terms of animal growth and carcass quality (Bedoin and Kristensen, 2013; Fraser et al., 2009). In addition, the spatial footprint of livestock rearing is relatively high.

The IntensiveMIN scenario is designed as a realistic intensive livestock production using the same land as the case farm. It assumes conventional livestock production, and local biophysical constraints are taken into account. Using a spatial overlay with the flood risk zone dataset in a GIS environment, frequently inundated parcels and zones showing high inundation risks were excluded for intensive livestock production. A similar approach was used to exclude parcels with species communities subject to the EU Habitat Directive. For reasons of comparison and to minimize dependency on off-farm land, we assumed the farm to be largely autonomous for feed production. In 2010, an average specialized Flemish livestock farm had 81.51 livestock units (LSU) on 30.47 hectares of grassland and an additional 35.48 hectares of feed production (Gavilan et al., 2012; Raes et al., 2011). Therefore, the IntensiveMIN alternative assume a spatial ratio between grassland and feed production of 0.86 .

Cluster 1 comprises the farm building associated infrastructure, and semi-natural grasslands with high levels of biodiversity. Cluster 2 consists mainly of biologically very valuable land dune ecosystems dominated by very nutrient-poor grass- and heathlands. Less than half of this cluster could be converted to intensive grazing lands. Cluster 3 mainly consist of wet, semi-natural grasslands and reedbeds. Frequent inundations here make most of the parcels unsuited for intensive grazing or feed production. Cluster 4 is located upstream in the subcatchment and consists of species rich grazing lands. Intensive grasslands and feed production are realistic land use alternatives. Cluster 5 mainly has wet grasslands where intensive grazing would be an option.

In the IntensiveMAX scenario, we formulate a corner solution where nearly all land of the case study area is taken into intensive production, irrespective of biophysical constraints that would make some lands unsuitable for intensive livestock production. As such this scenario would be difficult to establish within the spatial footprint of our case farm, but it provides an estimate of the differential output of ES of an unrestrained intensive livestock enterprise within the same catchments. The scenario assumes the removal of all small landscape elements such as hedgerows and isolated trees. Here too, maximal autonomy and a grassland over feed production spatial ratio of 0.86 is assumed.

Finally, the IntensiveSRC scenario explores the application of short rotation coppice (SRC) (willow and poplar) for biomass production in the most humid parcels. The cultivation of SRC can be seen as a relevant alternative strategy to increase the provisioning services 
delivered by the most humid parcels in this farming system. To select parcels for SRC production, a spatial overlay with the flooding risk zones was used and a total of 12.7 ha was selected. Willow (Salix spp.) was assumed for the parcels that effectively inundate, otherwise, poplar (Populus spp.) was assumed. All small landscape elements (single trees, hedgerows) and forest cover on land dunes remain in place. On the other parcels, livestock production remains as in the Reference scenario.

The land use distribution for each of these scenarios is provided in Table 1.

Table 1. Land use (in ha) for each cluster under different scenarios (see text for acronyms)

\begin{tabular}{|c|c|c|c|c|c|c|}
\hline & & & d Clust & & & \\
\hline & 1 & 2 & 3 & 4 & 5 & Total \\
\hline Reference & & & & & & \\
\hline Urban land & 0.5 & 0.1 & 0.0 & 0.0 & 0.0 & 0.6 \\
\hline Agriculture and pastures & 9.2 & 0.1 & 0.0 & 0.2 & 0.4 & 9.9 \\
\hline Rivers and ponds & 0.1 & $<0.1$ & $<0.1$ & 0.0 & $<0.1$ & 0.1 \\
\hline Wetlands & $<0.1$ & 0.0 & 0.9 & 0.0 & 1.3 & 2.2 \\
\hline Heath and land dunes & 1.4 & 6.0 & 0.0 & 0.0 & 0.0 & 7.4 \\
\hline Forests and shrubs & 3.0 & 6.1 & 0.0 & $<0.1$ & 6.7 & 15.8 \\
\hline Semi-natural grasslands & 35.6 & 9.3 & 4.9 & 4.5 & 22.0 & 76.3 \\
\hline IntensiveMIN & & & & & & \\
\hline Urban land & 0.5 & 0.1 & 0.0 & 0.0 & 0.0 & 0.6 \\
\hline Agriculture and pastures & 21.4 & 5.4 & 0.0 & 4.7 & 0.4 & 31.9 \\
\hline Rivers and ponds & 0.0 & 0.0 & $<0.1$ & 0.0 & $<0.1$ & $<0.1$ \\
\hline Wetlands & 0.0 & 0.0 & 0.9 & 0.0 & 1.3 & 2.2 \\
\hline Heath and land dunes & 1.4 & 6.0 & 0.0 & 0.0 & 0.0 & 7.4 \\
\hline Forests and shrubs & 2.8 & 6.1 & 0.0 & 0.0 & 6.7 & 15.6 \\
\hline Semi-natural grasslands & 23.7 & 4.0 & 4.9 & 0.0 & 22.0 & 54.6 \\
\hline IntensiveMAX & & & & & & \\
\hline Urban land & 0.5 & 0.1 & 0.0 & 0.0 & 0.0 & 0.6 \\
\hline Agriculture and pastures & 44.0 & 9.4 & 5.8 & 4.7 & 9.6 & 73.5 \\
\hline Rivers and ponds & 0.0 & 0.0 & 0.0 & 0.0 & 0.0 & 0.0 \\
\hline Wetlands & 0.0 & 0.0 & 0.0 & 0.0 & 1.3 & 1.3 \\
\hline Heath and land dunes & 1.4 & 6.0 & 0.0 & 0.0 & 0.0 & 7.4 \\
\hline Forests and shrubs & 2.8 & 6.1 & 0.0 & 0.0 & 6.7 & 15.6 \\
\hline Semi-natural grasslands & 1.1 & 0.0 & 0.0 & 0.0 & 12.8 & 13.9 \\
\hline IntensiveSRC & & & & & & \\
\hline Urban land & 0.5 & 0.1 & 0.0 & 0.0 & 0.0 & 0.6 \\
\hline Agriculture and pastures & 9.2 & 0.1 & 0.0 & 0.2 & 0.4 & 9.9 \\
\hline Rivers and ponds & 0.1 & 0.0 & 0.0 & 0.0 & 0.0 & 0.1 \\
\hline Wetlands & 0.0 & 0.0 & 0.9 & 0.0 & 1.3 & 2.2 \\
\hline Heath and land dunes & 1.4 & 6.0 & 0.0 & 0.0 & 0.0 & 7.4 \\
\hline Forests and shrubs & 13.3 & 6.1 & 2.4 & 0.0 & 6.7 & 28.5 \\
\hline Semi-natural grasslands & 25.3 & 9.3 & 2.5 & 4.5 & 22.0 & 63.6 \\
\hline
\end{tabular}




\section{$5 \quad$ Results}

For livestock production, the valuation tool estimates a mean yearly added value of $€$ 6971 (min: $€ 5$ 480, max: $€ 8$ 460) under the reference scenario. However, since nutrient-poor semi-natural grasslands are generally considered unsuitable for livestock production, the tool only takes parcels into account with intensive grasslands. Since the livestock breeds used enable the case farm to use most semi-natural grasslands for production, the production estimates for the Reference scenario were derived from the farm registers. According to the accountancy data of the case farm, a value for livestock production of 27000 euro is used for the Reference scenario. About 55\% of this output stems from meat production, while the remaining $45 \%$ results from live animal sales.

In terms of crop and livestock output, the IntensiveMIN and IntensiveMAX scenarios perform better than the Reference scenario, while the production value of the IntensiveSRC scenario is lower (table 2). The differences are much less obvious for the value of wood production, for which IntensiveSRC performs slightly better than the Reference.

For most regulating services that were taken into account, the Reference scenario is preferred over IntensiveMIN and IntensiveMAX, and is on par with IntensiveSRC. The exception here is the service 'air quality', for which IntensiveSRC is the best performer. The differences in terms of fine particle filtration (air quality) can be attributed to the presence of small landscape elements in the Reference scenario, and of coppice in the IntensiveSRC scenario. Differences are negligible for carbon storage services in biomass.

The value of the cultural services depends on the aesthetic value of the local landscape and is higher under the Reference scenario than under the IntensiveMIN and IntensiveMAX scenarios. The WTP for cultural services depends amongst others on the site area and number of households within a certain radius. Although relative WTP/ha is higher for smaller sites, the WTP per ha quickly decreases when households are living farther away from the site. This is in particular the case for smaller parcels that are remotely located. As such, for remote sites the site area has a strong positive impact on the valuation of the cultural benefits. The fact that the case farm is located relatively close to urban areas, has an outspoken positive impact on the cultural services provided under the Reference scenario.

Table 2 and Figure 2 compare the relative monetary value of ES delivered under the Reference scenario with these delivered by the other scenarios. The vertical line in the graph marks the Reference land use. Positive values in this table are situated to the right of this line and indicate that the alternative land use performs better that the Reference land use for that particular ES. The largest differences between the land use alternatives are in crop \& livestock production, air quality, and cultural services. Table 2 and Figure 2 illustrate that the potential societal benefits (in terms of selected ES) provided by bioproductive land of the case study is considerably higher in the Reference scenario than in the IntensiveMIN, but the difference between both is less obvious for the IntensiveMAX scenario. Of course one should take into consideration that IntensiveMAX is a corner solution that neglects biophysical constraints. 
Table 2. Aggregated differences in ES delivery between respective intensive scenarios and the Reference, based on conservative estimates. A negative value indicates the respective land use alternative performs worse than the Reference scenario, a positive value indicates it performs better.

\begin{tabular}{lccc} 
Ecosystem service & IntensiveMIN - Reference & IntensiveMAX - Reference & IntensiveSRC - Reference \\
\hline Crop \& livestock & 20200 & 65900 & -8900 \\
Wood & 300 & 500 & 3300 \\
Air quality & -7300 & -17450 & 17800 \\
C storage in soil & -100 & -5300 & 500 \\
C storage in biomass & -200 & -850 & 0 \\
N storage in soil & -4000 & -8850 & 0 \\
P storage in soil & -4250 & -9450 & 0 \\
Cultural services & -9250 & -23750 & 2600 \\
Total $(€)$ & $-\mathbf{4 6 0 0}$ & $\mathbf{7 5 0}$ & $\mathbf{1 5 3 0 0}$ \\
\hline
\end{tabular}

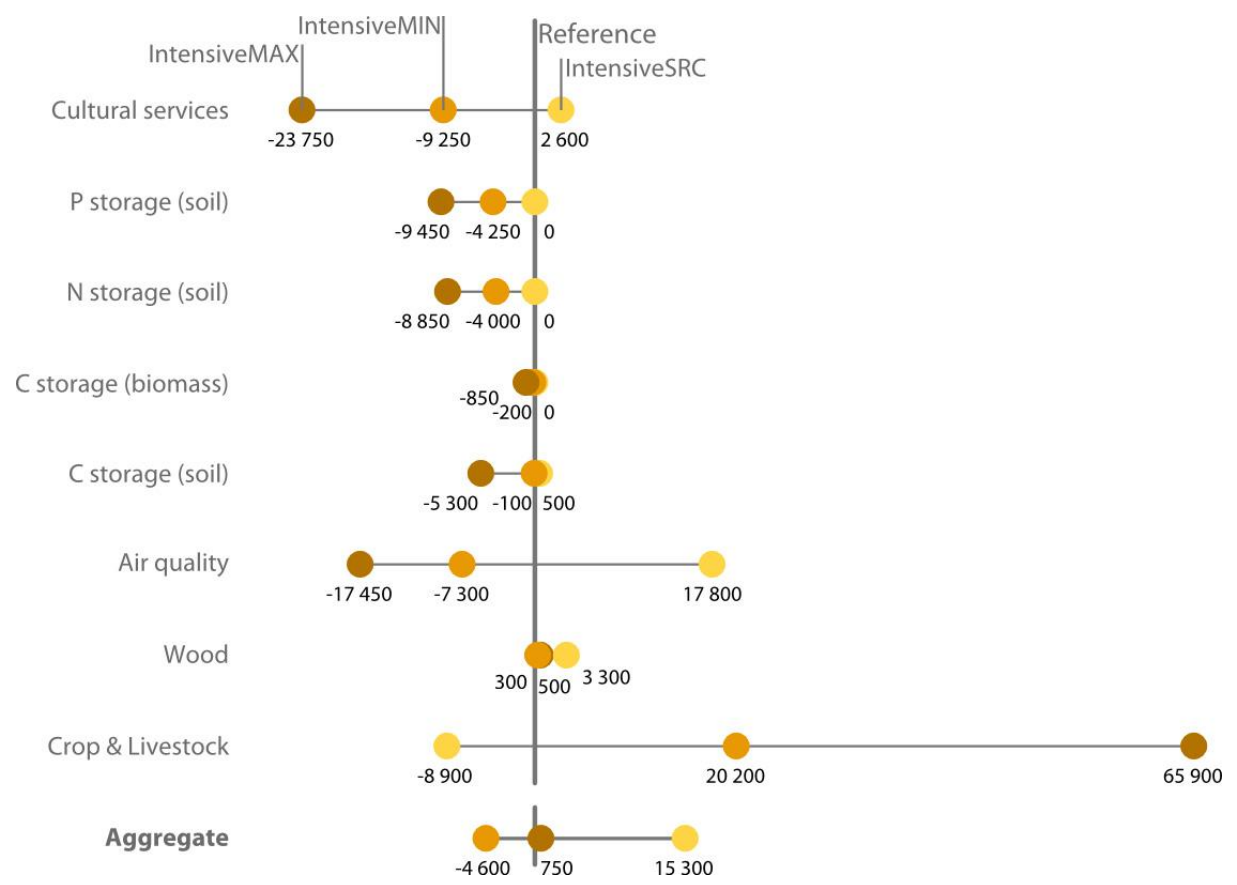

Figure 2. Relative differences in valued ecosystem service provision between the Reference scenario and the intensive scenarios. The central axis represents the Reference scenario. Alternatives performing better for a given ecosystem service are positioned to the right of this line, and alternatives performing worse are positioned to the left.

We compare land use scenarios by aggregating ES at 3 levels (Figure 3): (1) aggregation of only provisioning services; (2) aggregation of provisioning and regulating services, and (3) aggregation of all selected ecosystem services. The high relative proportion of nonmarketable ES and most notably, the influence of cultural ES becomes clear.

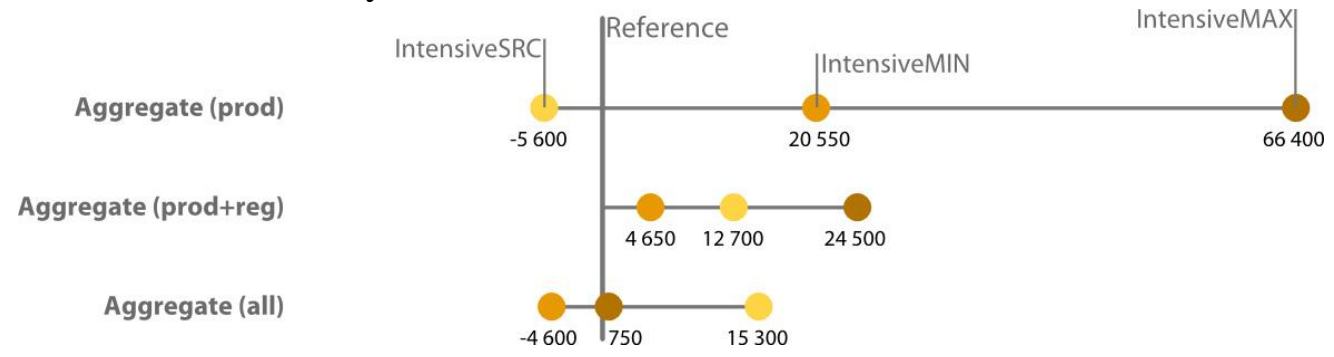

Figure 3. Comparison of aggregation based on (1) only provisioning services, (2) provisioning and regulating services, and (3) all selected ecosystem services (provisioning, regulating and cultural). 
The success of the Reference scenario relative to the IntensiveMin scenario relies in the successful adaptation of its production to biophysical constraints, to the benefit of both the natural environment and recreationists. While traditional cattle grazing preferably takes place on grasslands that are less subjected to inundation, the rustic cattle breed used by the case farm allows for grazing even on parcels that are effectively sensitive to flooding. As such, the farm realizes livestock output on natural flooding plains and thus acts as a buffer zone for water retention and reduces flooding risks in the downstream city of Diest. Parcels with tree cover and small landscape elements in turn are less suited for cattle breeding, but still allow for sheep grazing (Figure 4). Sheep provide grazing management on those parcels that inundate significantly less frequent (Wilcoxon $\mathrm{W}=130, \mathrm{p}<0.05$ ), but contain significantly more trees (Wilcoxon $\mathrm{W}=43, \mathrm{p}<0.05$ ). By using rustic cattle and sheep breeds on semi-natural grasslands and heathlands, the case farm reduces the biomass waste streams from these natural grasslands and contributes to reaching biodiversity targets.
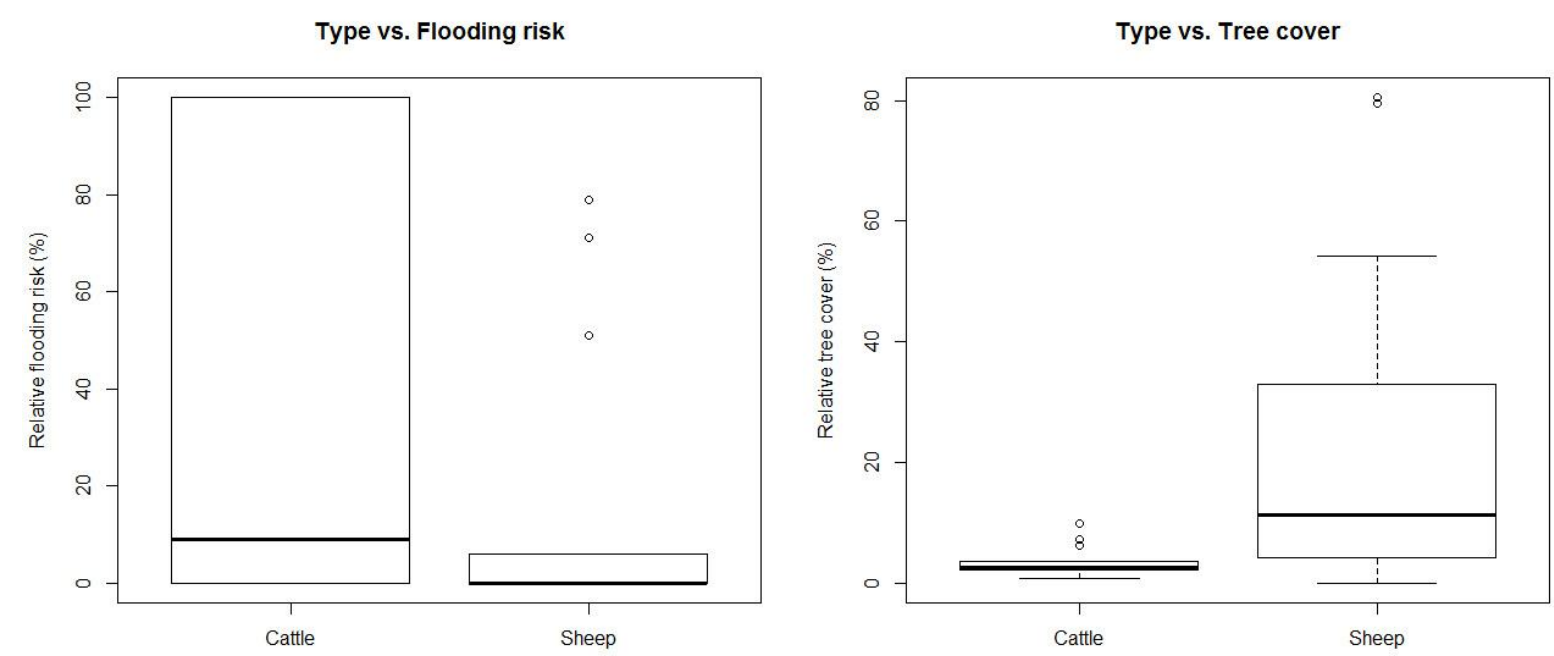

Figure 4. The use of cattle and sheep in an adaptive farming strategy: in relation to the flooding risk (left), and in relation to tree cover (right).

\section{Discussion}

Our results illustrate that optimal land use from a societal perspective depends on local biophysical constraints and the spatial and socio-economic context, and point out the importance of internalizing positive externalities. When land use scenarios are assessed by aggregating only provisioning services, the IntensiveMAX and IntensiveMIN would be preferred over the Reference, which in turn would be preferred over IntensiveSRC. This corresponds to an exclusively production-oriented rationale.

However, taking regulating and cultural services into account shifts the preference towards more unconventional land use alternatives. The presented case farm is illustrative for this, by using 'marginal' lands from a production perspective, largely relying on semi-natural grasslands, but nonetheless able to combine reasonable production levels with societal benefits that are higher than these provided under more conventional approaches (i.e. the 
IntensiveMin). Moreover, the farm's production model is serving the local biodiversity targets. The IntensiveSRC scenario performs relatively well, also in comparison with the Reference land use. Possible limiting factors for this development path can be spatial, economical, logistic, cultural, or related to legislation, e.g. conflicts with nature development targets. Future research is needed to reveal which, if any, factors are the most limiting. However, if biophysical constraints are less restricting, a situation corresponding to the IntensiveMAX scenario, the differences in delivering non-provisioning societal benefits decrease, making it harder for an organic farming system to outperform more intensive systems, even when multiple ecosystem services are taken into account. Hence, local biophysical constraints highly determine whether an organic farming system will outperform more intensive farming systems, confirming the importance of context (Pinto-Correia and Kristensen, 2013).

The comparison of the aggregates highlighted the relative importance of cultural ecosystems in the final outcome of the comparison. Cultural (recreation, amenity) values are gaining importance in rural economies (Domon, 2011). This poses several challenges for post-productivistic rural development. First, since cultural values are able to shift preferences towards one or the other land use alternative there is a clear need for robust valuation methods for cultural values (Plieninger et al., 2013). Second, landscapes with limited amenity values or that are undergoing development trends that compromise amenity values need special attention, since they risk being excluded from new rural economic development pathways (Domon, 2011). It is clear from the results that cultural ES play an important role for the outcome of the comparison. As such it is a priority to improve the validity and robustness of their estimation so that usual valuation tools, and particularly benefit transfer, can be improved.

According to the valuation method used, the value of cultural services depends on both local population densities and area size. Small sites are only valued by those living close by, while the cultural benefits of large and well connected sites are also valued by people living further away. As such, in a different spatial and socio-economic context (e.g. smaller sites that are not connected or lower population densities), the outcome of the evaluation of optimal land use strategies are expected to be very different, stressing the need for regionally adapted planning and management.

For the calculation of the ES, the study applies the "Ecosystem Service Valuation Tool" developed by VITO, which aims at being commonly used in various decision making processes in Flanders. This tool applies benefit transfer functions to estimate the value of the ES delivered by the considered bioproductive land. Benefit transfer functions apply values from existing studies, and the technique is widely applied in ES value assessments (Costanza et al., 1997; Schägner et al., 2013). However, it sometimes insufficiently accounts for the specific characteristics of study area of interest and fails to correctly estimate the ES delivered by innovative land uses. The main issue that we have encountered was associated with improperly evaluating the potential production associated with innovative forms of land use. This became clear when we calculated the value of crop and livestock production under the Reference scenario with the valuation tool and compared that estimate with the on-site production data. We found that the actual production was considerably outperforming the estimates based on the tool. The case farm does manage to use semi-natural grasslands and 
sell its meat to local customers by organizing periodical sales in collaboration with other producers of regional products. Meat from rustic breed is often not suited for conventional meat markets and requires 'alternative' markets with different quality criteria (e.g. sustainable, good taste, local, ...) (Bedoin \& Kristensen, 2013). With an estimated live weight gain of about $800 \mathrm{~g} / \mathrm{day}$, the Kempisch Roodbont, which is used on the case farm, performs relatively well. Kempisch Roodbont has the added advantage of being suited for both milk and meat production. By comparison, research by Pelve et al. (2012) on livestock productivity on semi-natural grasslands indicates that live weight gain of about 400 to $500 \mathrm{~g} /$ day is feasible using adapted breeds.

While the tool lends itself well for estimated conventional livestock farming production, decision making based on it can be biased against non-conventional livestock production potential in natural areas. Hence, if land planners rely on usual ES valuation tools, i.e. tools that fail to estimate the contribution of innovative land uses, then they might wrongly assess and arbitrate between land sharing and sparing. This stresses the need to highlight the potential of agro-ecological innovations through in-depth case studies, and take them into account in spatial planning processes. Key innovations here are the use of adapted rustic breeds, paired with efforts to close nutrient cycles within the production system. Further, the added value of agro-ecological innovations that rely on land use interactions and complementarities, such as buffer strips or agroforestry, are not yet included in the methodology, while it is an important lever for spatial planning to work with. These challenges can be addressed using spatially explicit GIS-based tools (e.g. Jackson et al., 2013; von Haaren et al., 2012), but often at the expense of accessibility and ease of use. Despite being based on benefit transfer functions, our analysis already requires a considerable level of detail and a link with land management economics. Hence, it might be more challenging to comprehend, as argued by Jackson et al. (2013).

The objective of the research is not to provide an absolute valuation of the ES delivered, but rather a relative positioning of potential land use alternatives that might emerge in the area considered. Obviously, some assumptions needed to be made in drafting the counterfactual scenarios. The scenarios were drafted in close collaboration with the farmer, to make sure they were realistic given the landscape context (with the obvious exception of the corner solution).

The extensive farming model co-evolves in response to very common nature management strategies in developed regions such as Flanders, where ecosystems are dealing with excess nutrient loads. Through combined grazing and cutting management, nutrients are removed from the system and floristic diversity is able to increase. This grazing and cutting management should at minimum compensate for the nutrient influx through dry and wet deposition, but from a floristic diversity perspective, it is desirable for the system to progressively become more nutrient poor. On-farm diversification is aiming to validate this biodiversity, e.g. by engaging in ecotourism, but also subsidies and payments for ES that partially enable to internalize positive externalities. While the Reference scenario is able to outperform the IntensiveMIN farming strategy, and is almost on par with the IntensiveMAX corner solution when taking a wider range of ES into account, the increasingly limited income for farmers remains a cause of concern. The case farm is partially dependent on additional government subsidies and this adds to its vulnerability. 
Some functions and services provided under the Reference scenario are still underestimated. First, the case farm manages to valorize the biodiversity in its surrounding through ecotourism. Revenues from ecotourism are not included in the valuation of the land use scenarios. Second, as agricultural research faces a lock-in that favors innovations in the field of genetic engineering and risks locking out agro-ecological innovations (Vanloqueren and Baret, 2009, 2008), this case illustrates the potential of using selected rare breeds and generates positive externalities through the conservation of genetic resources. Third, several parcels managed by the case farm inundate regularly, contributing to the flooding risk reduction for a nearby provincial town. This flood protection service delivered by the case farm is also not yet taken into account.

\section{Conclusion}

Like many urbanized regions, Flanders is characterized by a high degree of polarization between expanding urbanized tissue and the remaining open space used for agriculture, with natural areas largely pushed back to relatively small and fragmented relics. As pressure on remaining open spaces increases, more actors adopt a conservational attitude of safeguarding a spatial niche from claims of other sectors. However, there is growing awareness that one spatial niche can provide services that are beneficial to several sectors. Not surprisingly, efforts to reconcile food production with ecosystem rehabilitation in Flanders have therefore mainly been focusing on land sharing strategies. While nature organizations are increasingly willing to cooperate with livestock farmers, many farmers show little interest in managing nutrient-poor or wet grasslands. In addition, some land sharing strategies, in particular agrienvironmental schemes, are not achieving the expected results (Balmford et al., 2012; Kleijn et al., 2011; Pe'er et al., 2014). This makes it difficult for land planners to assess whether a land sharing or sparing policy is preferable. An assessment and valuation of all ES provided by bioproductive land (i.e. of marketable and non-marketable ES as well as of ES delivered by conventional and non-conventional production methods) can be used as a framework to evaluate land use strategies. These land use alternatives can either focus on integrating various ES (i.e. a land sharing strategy), or can rather spatially segregate ES (i.e. land sparing). As such, the framework can contribute to resolving land sharing or sparing dilemmas and allows decision makers to better arbitrate between these land use alternatives. Breaking down the potential societal benefits provided by different land uses into a number of different ecosystem services, provides opportunities for policy makers to design wellinformed and targeted policies, e.g. by defining local targets for specific ecosystem services, or compensate non-marketable ES using payments for ecosystems (PES) schemes (Ghaley et al., 2013). The framework looks at both marketable and non-marketable ES and expresses both in monetary terms. As such positive externalities associated with different land use alternatives can be highlighted more easily. By identifying functions and services that are underestimated by existing evaluation tools, it is possible to recognize agro-ecological innovations that are otherwise largely neglected.

In our study we apply an integrative approach in close collaboration with the case farm owner, to evaluate the farm's land use and compare it with realistic alternative land use scenarios. This approach is also vital to gain insights in potential innovative aspects of the 
land use alternatives (cf. Nassauer, 2012). The results suggest that the agro-ecological land use strategy of this farm may or may not be preferred over more conventional land use strategies, depending on the services that are taken into account, the biophysical constraints and the socio-economic context. The analysis highlights the potential of the agro-ecological land use to provide higher levels of societal benefits (i.e. output of ES) in regions with both 'inferior' and high quality land and with high population densities. However, if there are no biophysical constraints, if the potential area for extensive land management is small and/or not connected, or if the population density is low, the intensive land use strategies might outperform agro-ecological land use strategies. A local demand for ES can thus be addressed by a multitude of different farming models (Cunningham et al., 2013; Firbank et al., 2012).

This paper contributes to the challenge of adaptive land management and spatial planning by expanding the concept of agricultural productivity to bioproductivity, as a means to integrate seemingly competing services. Although applied here to the farm scale, the ESbased approach could be applied to the landscape scale, and in complex regions. This would however, require a different line of transdisciplinary work, involving more stakeholders. Further development of this approach should inspire the integration of the hitherto separated disciplines of spatial planning and land management.

\section{Acknowledgements}

The presented research was funded by the Flemish Policy Research Centre on Space. The authors like to thank V. Dewaelheyns for inspiring discussions on the topic, and the reviewers for constructive comments on this manuscript.

\section{References}

Aerodata International Surveys, 2007. Aerial imagery.

AGIV, 2006. Digitale bodemkaart van het Vlaams Gewest (Flemish digital soil map).

AGIV, 2010. Biologische Waarderingskaart (Biological Valuation Map) v2.

Ahern, J., Cilliers, S., Niemelä, J., 2014. The concept of ecosystem services in adaptive urban planning and design: A framework for supporting innovation. Landsc. Urban Plan. 125, 254-259. doi:10.1016/j.landurbplan.2014.01.020

ANB, 2010. Groenkaart (Vegetation map) 2010.

ANB, 2013. Groenkaart (Vegetation map) 2013.

Balmford, A., Green, R., Phalan, B., 2012. What conservationists need to know about farming. Proc. Biol. Sci. 279, 2714-24. doi:10.1098/rspb.2012.0515

Bateman, I.J., Day, B.H., Jones, A.P., Jude, S., 2009. Reducing gain-loss asymmetry: A virtual reality choice experiment valuing land use change. J. Environ. Econ. Manage. 58, 106-118. doi:10.1016/j.jeem.2008.05.003

Bedoin, F., Kristensen, T., 2013. Sustainability of grassland-based beef production - Case studies of Danish suckler farms. Livest. Sci. 158, 189-198. doi:10.1016/j.livsci.2013.10.006 
Bomans, K., Dewaelheyns, V., Gulinck, H., 2009. Missing categories in open space planning, in: Brebbia, C.A., Neophytou, M., Beriatos, E., loannou, I., Kungolos, A.G. (Eds.), Sustainable Development and Planning Iv, Vols 1 and 2. Wit Press, Southampton, pp. 317-327. doi:10.2495/sdp090311

Bomans, K., Steenberghen, T., Dewaelheyns, V., Leinfelder, H., Gulinck, H., 2010. Underrated transformations in the open space-The case of an urbanized and multifunctional area. Landsc. Urban Plan. 94, 196-205. doi:10.1016/j.landurbplan.2009.10.004

Boody, G., Vondracek, B., Andow, D.A., Krinke, M., Zimmerman, J., Welle, P., 2013. Multifunctional Agriculture in the United States 55, 27-38.

Broch, S.W., Strange, N., Jacobsen, J.B., Wilson, K. a., 2013. Farmers' willingness to provide ecosystem services and effects of their spatial distribution. Ecol. Econ. 92, 78-86. doi:10.1016/j.ecolecon.2011.12.017

Broekx, S., Liekens, I., Peelaerts, W., De Nocker, L., Landuyt, D., Staes, J., Meire, P., Schaafsma, M., Van Reeth, W., Van den Kerckhove, O., Cerulus, T., 2013. A web application to support the quantification and valuation of ecosystem services. Environ. Impact Assess. Rev. 40, 65-74. doi:10.1016/j.eiar.2013.01.003

Broekx, S., Meynaerts, E., Vercaemst, P., 2009. Milieukostenmodel Water voor Vlaanderen. Berekeningen voor het stroomgebiedbeheerplan 2009.

Burkhard, B., Kroll, F., Nedkov, S., Müller, F., 2012. Mapping ecosystem service supply, demand and budgets. Ecol. Indic. 21, 17-29. doi:10.1016/j.ecolind.2011.06.019

Castro, A.J., Verburg, P.H., Martín-López, B., Garcia-Llorente, M., Cabello, J., Vaughn, C.C., López, E., 2014. Ecosystem service trade-offs from supply to social demand: A landscape-scale spatial analysis. Landsc. Urban Plan. 132, 102-110. doi:10.1016/j.landurbplan.2014.08.009

Christensen, T., Pedersen, A.B., Nielsen, H.O., Mørkbak, M.R., Hasler, B., Denver, S., 2011. Determinants of farmers' willingness to participate in subsidy schemes for pesticide-free buffer zones-A choice experiment study. Ecol. Econ. 70, 1558-1564. doi:10.1016/j.ecolecon.2011.03.021

Cook, E.M., Hall, S.J., Larson, K.L., 2012. Residential landscapes as social-ecological systems: a synthesis of multi-scalar interactions between people and their home environment, Urban Ecosystems. doi:10.1007/s11252-011-0197-0

Costanza, R., D’Arge, R., de Groot, R., Farber, S., Grasso, M., Hannon, B., Limburg, K., Naeem, S., O'Neill, R. V., Paruelo, J., Raskin, R.G., Sutton, P., van den Belt, M., 1997. The value of the world's ecosystem services and natural capital. Nature. doi:10.1038/387253a0

Crossman, N.D., Burkhard, B., Nedkov, S., Willemen, L., Petz, K., Palomo, I., Drakou, E.G., MartínLopez, B., McPhearson, T., Boyanova, K., Alkemade, R., Egoh, B., Dunbar, M.B., Maes, J., 2013. A blueprint for mapping and modelling ecosystem services. Ecosyst. Serv. 4, 4-14. doi:10.1016/j.ecoser.2013.02.001

Cunningham, S. a., Attwood, S.J., Bawa, K.S., Benton, T.G., Broadhurst, L.M., Didham, R.K., Mclntyre, 
S., Perfecto, I., Samways, M.J., Tscharntke, T., Vandermeer, J., Villard, M.A., Young, A.G., Lindenmayer, D.B., 2013. To close the yield-gap while saving biodiversity will require multiple locally relevant strategies. Agric. Ecosyst. Environ. 173, 20-27. doi:10.1016/j.agee.2013.04.007

Dale, V.H., Polasky, S., 2007. Measures of the effects of agricultural practices on ecosystem services. Ecol. Econ. 64, 286-296. doi:10.1016/j.ecolecon.2007.05.009

Daniel, F.J., 2008. Variations in rural development: a comparative analysis of the application of the Rural Development Regulation Framework in France and the Netherlands. NJAS - Wageningen J. Life Sci. 56, 7-19. doi:10.1016/S1573-5214(08)80014-0

de Groot, R., 2006. Function-analysis and valuation as a tool to assess land use conflicts in planning for sustainable, multi-functional landscapes. Landsc. Urban Plan. 75, 175-186. doi:10.1016/j.landurbplan.2005.02.016

De Nocker, L., Michiels, H., Deutsch, F., Lefebvre, W., Buekers, J., Torfs, R., 2010. Actualisering van de externe milieuschadekosten (algemeen voor Vlaanderen) met betrekking tot luchtverontreiniging en klimaatverandering, studie uitgevoerd in opdracht van de Vlaamse Milieumaatschappij, MIRA. VITO.

De Valck, J., Vlaeminck, P., Broekx, S., Liekens, I., Aertsens, J., Chen, W., Vranken, L., 2014. Landscape and Urban Planning Benefits of clearing forest plantations to restore nature ? Evidence from a discrete choice experiment in Flanders, Belgium. Landsc. Urban Plan. 125, 65-75. doi:10.1016/j.landurbplan.2014.02.006

Dewaelheyns, V., Rogge, E., Gulinck, H., 2014. Putting domestic gardens on the agenda using empirical spatial data: The case of Flanders. Appl. Geogr. 50, 132-143. doi:10.1016/j.apgeog.2014.02.011

Domon, G., 2011. Landscape as resource: Consequences, challenges and opportunities for rural development. Landsc. Urban Plan. 100, 338-340. doi:10.1016/j.landurbplan.2011.02.014

Estrada-Carmona, N., Hart, A.K., DeClerck, F. a. J., Harvey, C. a., Milder, J.C., 2014. Integrated landscape management for agriculture, rural livelihoods, and ecosystem conservation: An assessment of experience from Latin America and the Caribbean. Landsc. Urban Plan. 129, 111. doi:10.1016/j.landurbplan.2014.05.001

Firbank, L., Bradbury, R.B., McCracken, D.I., Stoate, C., 2012. Delivering multiple ecosystem services from Enclosed Farmland in the UK. Agric. Ecosyst. \&amp; Environ.

Foley, J. a, Defries, R., Asner, G.P., Barford, C., Bonan, G., Carpenter, S.R., Chapin, F.S., Coe, M.T., Daily, G.C., Gibbs, H.K., Helkowski, J.H., Holloway, T., Howard, E. a, Kucharik, C.J., Monfreda, C., Patz, J. a, Prentice, I.C., Ramankutty, N., Snyder, P.K., 2005. Global consequences of land use. Science 309, 570-574. doi:10.1126/science.1111772

Fraser, M.D., Davies, D.A., Vale, J.E., Nute, G.R., Hallett, K.G., Richardson, R.I., Wright, I.A., 2009. Performance and meat quality of native and continental cross steers grazing improved upland pasture or semi-natural rough grazing. Livest. Sci. 123, 70-82. doi:10.1016/j.livsci.2008.10.008

Gavilan, J., Deuninck, J., Somers, L., D’hooghe, J., 2012. Rentabiliteits- en kostprijsanalyse vleesvee. 
Departement Landbouw en Visserij, Afdeling Monitoring en Studie.

Ghaley, B.B., Vesterdal, L., Porter, J.R., 2013. Quantification and valuation of ecosystem services in diverse production systems for informed decision-making. Environ. Sci. Policy 1-11. doi:10.1016/j.envsci.2013.08.004

Gulinck, H., Marcheggiani, E., Lerouge, F., Dewaelheyns, V., 2013. The landscape of interfaces: painting outside the lines, in: Newman, C., Nussaume, Y., Pedroli, B. (Eds.), Landscape \& Imagination: Towards a New Baseline for Education in a Changing World. Uniscape, Paris.

Haines-Young, R., Potschin, M., 2010. Proposal for a Common International Classification of Ecosystem Goods and Services ( CICES ) for Integrated Environmental and Economic Accounting.

Hauck, J., Görg, C., Varjopuro, R., Ratamäki, O., Jax, K., 2013. Benefits and limitations of the ecosystem services concept in environmental policy and decision making: Some stakeholder perspectives. Environ. Sci. Policy 25, 13-21. doi:10.1016/j.envsci.2012.08.001

Hoyos, D., 2010. The state of the art of environmental valuation with discrete choice experiments. Ecol. Econ. 69, 1595-1603. doi:10.1016/j.ecolecon.2010.04.011

INBO, 2010. Habitatkaart (Habitat map) v5.2.

Jackson, B., Pagella, T., Sinclair, F., Orellana, B., Henshaw, A., Reynolds, B., Mclntyre, N., Wheater, H., Eycott, A., 2013. Polyscape: A GIS mapping framework providing efficient and spatially explicit landscape-scale valuation of multiple ecosystem services. Landsc. Urban Plan. 112, 74-88. doi:http://dx.doi.org/10.1016/j.landurbplan.2012.12.014

Jansen, J.J., Sevenster, J., Faber, P.J., 1996. Opbrengst tabellen voor belangrijke boomsoorten in Nederland, IBN rapport.

Kerselaers, E., Rogge, E., Vanempten, E., Lauwers, L., Van Huylenbroeck, G., 2013. Changing land use in the countryside: Stakeholders' perception of the ongoing rural planning processes in Flanders. Land use policy 32, 197-206. doi:10.1016/j.landusepol.2012.10.016

Kleijn, D., Rundlöf, M., Scheper, J., Smith, H.G., Tscharntke, T., 2011. Does conservation on farmland contribute to halting the biodiversity decline? Trends Ecol. Evol. 26, 474-481. doi:10.1016/j.tree.2011.05.009

Laterra, P., Orúe, M.E., Booman, G.C., 2012. Spatial complexity and ecosystem services in rural landscapes. Agric. Ecosyst. Environ. 154, 56-67. doi:http://dx.doi.org/10.1016/j.agee.2011.05.013

Leinfelder, H., 2007. Open Ruimte als Publieke Ruimte. Academia Press.

Liekens, I., Schaafsma, M., De Nocker, L., Broekx, S., Staes, J., Aertsens, J., Brouwer, R., $2013 a$. Developing a value function for nature development and land use policy in Flanders, Belgium. Land use policy 30, 549-559. doi:10.1016/j.landusepol.2012.04.008

Liekens, I., Van der Biest, K., Staes, J., De Nocker, L., Aertsens, J., Broekx, S., 2013b. Waardering van ecosysteemdiensten, een handleiding., Studie in opdracht van LNE, afdeling milieu-, natuur- en energiebeleid. 
Meersmans, J., De Ridder, F., Canters, F., De Baets, S., Van Molle, M., 2008. A multiple regression approach to assess the spatial distribution of Soil Organic Carbon (SOC) at the regional scale (Flanders, Belgium). Geoderma 143, 1-13. doi:10.1016/j.geoderma.2007.08.025

Meeus, B., De Decker, P., 2013. De geest van suburbia. Garant Publishers, Antwerp.

Meyfroidt, P., Lambin, E.F., Erb, K.-H., Hertel, T.W., 2013. Globalization of land use: distant drivers of land change and geographic displacement of land use. Curr. Opin. Environ. Sustain. 5, 438-444. doi:10.1016/j.cosust.2013.04.003

Millennium Ecosystem Assessment, 2005. Ecosystems and Human Well-being: Bidoversity Synthesis. World Resources Institute, Washington DC.

Nassauer, J.I., 2012. Landscape as medium and method for synthesis in urban ecological design. Landsc. Urban Plan. 106, 221-229. doi:10.1016/j.landurbplan.2012.03.014

Oelmann, Y., Broll, G., Hölzel, N., Kleinebecker, T., Vogel, A., Schwartze, P., 2009. Nutrient impoverishment and limitation of productivity after 20 years of conservation management in wet grasslands of north-western Germany. Biol. Conserv. 142, 2941-2948. doi:10.1016/j.biocon.2009.07.021

Oosterbaan, A., Tonneijck, A.E.G., de Vries, E.A., 2006. Kleine landschapselementen als invangers van fijn stof en ammoniak, Alterra-rapport. Alterra.

Pe'er, G., Dicks, L. V, Visconti, P., Arlettaz, R., Báldi, A., Benton, T.G., Collins, S., Dieterich, M., Gregory, R.D., Hartig, F., Henle, K., Hobson, P.R., Kleijn, D., Neumann, R.K., Robijns, T., Schmidt, J., Shwartz, A., Sutherland, W.J., Turbé, A., Wulf, F., Scott, a V, 2014. EU agricultural reform fails on biodiversity. Science (80-. ). 344, 1090-1092. doi:10.1126/science.1253425

Pinto-Correia, T., Kristensen, L., 2013. Linking research to practice: The landscape as the basis for integrating social and ecological perspectives of the rural. Landsc. Urban Plan. 120, 248-256. doi:10.1016/j.landurbplan.2013.07.005

Plieninger, T., Dijks, S., Oteros-Rozas, E., Bieling, C., 2013. Assessing, mapping, and quantifying cultural ecosystem services at community level. Land use policy 33, 118-129. doi:10.1016/j.landusepol.2012.12.013

Portman, M.E., 2013. Ecosystem services in practice: Challenges to real world implementation of ecosystem services across multiple landscapes - A critical review. Appl. Geogr. 45, 185-192. doi:10.1016/j.apgeog.2013.09.011

Radford, K.G., James, P., 2013. Changes in the value of ecosystem services along a rural-urban gradient: A case study of Greater Manchester, UK. Landsc. Urban Plan. 109, 117-127. doi:http://dx.doi.org/10.1016/j.landurbplan.2012.10.007

Raes, W., Bernaerts, E., Demuynck, E., Oeyen, A., Tacquenier, B., 2011. Economische resultaten van de Vlaamse land- en tuinbouw. Departement Landbouw en Visserij, Afdeling Monitoring en Studie.

Ryffel, A.N., Rid, W., Grêt-Regamey, A., 2014. Land use trade-offs for flood protection: A choice 
experiment with visualizations. Ecosyst. Serv. 10, 111-123. doi:10.1016/j.ecoser.2014.09.008

Schaafsma, M., Brouwer, R., Liekens, I., De Nocker, L., 2014. Temporal stability of preferences and willingness to pay for natural areas in choice experiments: A test-retest. Resour. Energy Econ. 38, 243-260. doi:10.1016/j.reseneeco.2014.09.001

Schägner, J.P., Brander, L., Maes, J., Hartje, V., 2013. Mapping ecosystem services' values: Current practice and future prospects. Ecosyst. Serv. 4, 33-46. doi:http://dx.doi.org/10.1016/j.ecoser.2013.02.003

Stevens, C.J., Duprè, C., Dorland, E., Gaudnik, C., Gowing, D.J.G., Bleeker, A., Diekmann, M., Alard, D., Bobbink, R., Fowler, D., Corcket, E., Mountford, J.O., Vandvik, V., Aarrestad, P.A., Muller, S., Dise, N.B., 2011. The impact of nitrogen deposition on acid grasslands in the Atlantic region of Europe. Environ. Pollut. 159, 2243-50. doi:10.1016/j.envpol.2010.11.026

Swinton, S.M., Lupi, F., Robertson, G.P., Hamilton, S.K., 2007. Ecosystem services and agriculture: Cultivating agricultural ecosystems for diverse benefits. Ecol. Econ. 64, 245-252.

Termorshuizen, J., Opdam, P., 2009. Landscape services as a bridge between landscape ecology and sustainable development. Landsc. Ecol. 24, 1037-1052. doi:10.1007/s10980-008-9314-8

Tscharntke, T., Clough, Y., Wanger, T.C., Jackson, L., Motzke, I., Perfecto, I., Vandermeer, J., Whitbread, A., 2012. Global food security, biodiversity conservation and the future of agricultural intensification. Biol. Conserv. 151, 53-59. doi:10.1016/j.biocon.2012.01.068

Turner, K.G., Odgaard, M.V., Bøcher, P.K., Dalgaard, T., Svenning, J.-C., 2014. Bundling ecosystem services in Denmark: Trade-offs and synergies in a cultural landscape. Landsc. Urban Plan. 125, 89-104. doi:10.1016/j.landurbplan.2014.02.007

Van Broekhoven, E., Somers, L., Tacquenier, B., 2012. Overzicht van de boekhoudkundige resultaten van 749 land- en tuinbouwbedrijven Boekjaar 2010 Landbouwmonitoringsnetwerk. Beleidsdomein Landbouw en Visserij, afdeling Monitoring en Studie.

van de Walle, I., van Camp, N., Perrin, D., Lemeur, R., Verheyen, K., Van Wesemael, B., Laitat, E., 2005. Growing stock-based assessment of the carbon stock in the Belgian forest biomass. Ann. For. Sci. 62, 853-864. doi:1854/5390

Vanloqueren, G., Baret, P. V, 2008. Why are ecological, low-input, multi-resistant wheat cultivars slow to develop commercially? A Belgian agricultural "lock-in" case study. Ecol. Econ. 66, 436446. doi:10.1016/j.ecolecon.2007.10.007

Vanloqueren, G., Baret, P. V, 2009. How agricultural research systems shape a technological regime that develops genetic engineering but locks out agroecological innovations. Res. Policy $38,971-$ 983. doi:10.1016/j.respol.2009.02.008

Verhoeve, A., Dewaelheyns, V., Kerselaers, E., Rogge, E., Gulinck, H., 2015. Virtual farmland: Grasping the occupation of agricultural land by non-agricultural land uses. Land use policy 42, 547-556. doi:10.1016/j.landusepol.2014.09.008

VMM, 2006. Watertoetskaarten. 
von Haaren, C., Kempa, D., Vogel, K., Rüter, S., 2012. Assessing biodiversity on the farm scale as basis for ecosystem service payments. J. Environ. Manage. 113, 40-50. doi:10.1016/j.jenvman.2012.07.033

Vuylsteke, A., Bergen, D., Demuynck, E., 2014. Schaalgrootte en schaalvergroting in de Vlaamse land en tuinbouw. Brussel.

Wainger, L.A., King, D.M., Mack, R.N., Price, E.W., Maslin, T., 2010. Can the concept of ecosystem services be practically applied to improve natural resource management decisions? Ecol. Econ. 69, 978-987. doi:10.1016/j.ecolecon.2009.12.011

Zasada, I., 2011. Multifunctional peri-urban agriculture-A review of societal demands and the provision of goods and services by farming. Land use policy $28,639-648$.

doi:10.1016/j.landusepol.2011.01.008 